\title{
Structuring diluted wheat matrices: impact of heat moisture treatment on protein aggregation and viscoelasticity of hydrated composite flours
}

\author{
Concha Collar ${ }^{\mathrm{a}^{*}}$, Marina Villanueva ${ }^{\mathrm{b}}$, Felicidad Ronda $^{\mathrm{b}}$ \\ ${ }^{a}$ Cereals and Cereal-based Products. Food Science Department. Instituto de Agroquímica y Tecnología de \\ Alimentos (CSIC). Avda. Catedrático Agustín Escardino, 7. 46980 Paterna. Spain. \\ ${ }^{b}$ Department of Agriculture and Forestry Engineering, Food Technology, College of Agricultural and Forestry \\ Engineering. University of Valladolid. Avda. Madrid, 44. 34004 Palencia, Spain \\ *Corresponding author. Tel.: +34 9639000 22; Fax: +34 963636301 \\ E-mail address: ccollar@iata.csic.es
}

\begin{abstract}
The influence of heat-moisture treatment (HMT) and flour hydration (DY) on the restoration of dough viscoelasticity of wheat/non-wheat binary matrices was investigated by applying fundamental and empirical rheological procedures, and the protein structural reorganisation was monitored by measuring residual protein solubility in different media, and by assessing the accessibility of thiol groups inside the protein network. Single chestnut $(\mathrm{CN})$, chickpea $(\mathrm{CP})$, millet $(\mathrm{MI})$ and teff $(\mathrm{T})$ flour samples submitted to HMT $\left(15 \%\right.$ moisture content, $1 \mathrm{~h}$ and $\left.120^{\circ} \mathrm{C}\right)$ were blended with wheat flour at $10 \%(\mathrm{CN}$, $\mathrm{CP}$ ) and $30 \%$ (MI, T) of replacement, and binary matrices hydrated at low (L), medium (M) and high (H) DY. Structuring ability of HMT was mainly observed in cereal flour blends (T, MI), where higher elastic moduli and lower loss tangent together with solid-like elastic structure over higher shear stress were observed as compared with treated non-cereal flour blends (CN. CP). Increased flour hydration significantly weakened blends structure, inducing a stepped decrease in dynamic moduli values particularly noticed in cereal blends at highest level of flour hydration, and a shift from elastic-like to viscous-like structure at lower shear stress in non-wheat cereal matrices. The formation of a protein network with reinforced compact structure associated to the presence or formation of intramolecular $(\mathrm{CN}, \mathrm{CP}, \mathrm{T})$ and intermolecular disulphide bonds $(\mathrm{CN}, \mathrm{CP}, \mathrm{MI}, \mathrm{T})$, water soluble $(\mathrm{CN}, \mathrm{MI})$ and water insoluble aggregates $(\mathrm{CP}, \mathrm{T})$ is feasible to achieve with proteins of non-wheat flours submitted to HMT, particularly in high DY doughs. The lower the amount of free thiols in high molecular weight proteins encompassing high degree of crosslinking, corresponded to thermally treated samples (T, MI) blended at $\mathrm{L}$ and $\mathrm{M}$ hydration levels. For thermally treated samples, the lower the amount of free thiols in high molecular weight proteins encompassing high degree of crosslinking, corresponded to $\mathrm{T}$ and MI binary matrices blended at $\mathrm{L}$ and $\mathrm{M}$ hydration levels. These samples exhibited a solid-like elastic structure over higher shear stress and showed increased tolerance to stress/ strain before losing the structure.
\end{abstract}

Keywords: Teff $\cdot$ Millet $\cdot$ Chestnut $\cdot$ Chickpea $\cdot$ Protein aggregation $\cdot$ Viscoelasticity

\section{Introduction}

Partial wheat flour replacement by nutrient-dense and health-promoting flours such as non-wheat cereal and non-cereal flours constitutes a plausible simple strategy to create added value to baked goods. This strategy has been successfully applied recently to diluted wheat matrices blended with ancient crops, 
minor cereals, pseudocereals, legumes, and non-traditional fruit and seed flours (Collar, 2016; Paciulli et al. 2016).

Among non-wheat flours, millets, chestnut, teff and chickpea flours can provide extra nutritional, health and/or functional promoting effects when incorporated into breadmaking systems. Chestnut flour contains high-quality proteins with essential amino acids, dietary fiber, low amount of fat, and also vitamins (E, B groups) and minerals (K, P, and $\mathrm{Mg}$ ) of nutritional interest on both wheat (Dall'Asta et al. 2013) and gluten-free (Paciulli et al. 2016) breadmaking applications. Legumes constitute wholesome imaged foods providing nutritional (high protein, mineral and fiber contents, low digestible starch), health (protective and therapeutic effects to chronic health conditions), and functional promoting effects (body, texture, and taste enhancement) to foods (Angioloni and Collar 2012a). Associated mixtures of grain (chickpea, green pea) and oilseed (soybean) legumes in highly replaced wheat flour systems provided highly nutritious breads meeting viscoelastic restrictions and sensory standards (Collar and Angioloni 2017). Teff (Eragrostis tef), a nutritious cereal wheat-type gluten-free grain, rich in carbohydrates and fibre, microelements, and phytochemicals (Abebe et al. 2007), was successfully applied in breadmaking matrices up to $40 \%$ of wheat replacement (Ronda et al. 2015). Millets contain substantial levels of various phenolic compounds (Bagdi et al., 2011), much higher than in wheat, and they exhibit cholesterol lowering properties (Cho et al., 2000). With these attributes millets exhibit a huge potential for food production, and in particular for bread baking (Angioloni and Collar, 2012b, 2013a).

Extensive replacement of wheat flour by non-wheat flours to achieve nutritional and health related benefits, often encompasses an impairment of the physic-chemical attributes of resulting breads, since flours are gluten-free and unable to form a three-dimensional viscoelastic protein network.

Heat moisture treatment (HMT) constitutes a clean label alternative to chemical modification for altering the aggregation/disaggregation equilibrium of proteins (Mann et al., 2013) and the gelatinization and retrogradation properties of flours (Collar, 2017) and doughs (Collar and Armero, 2018a), providing promoted viscoelasticity of hydrated gluten-free flours. HMT of flours has successfully been applied to composite non-wheat-wheat flours to improve both volume and textural profile of the resulting breads (Collar and Armero, 2018b, 2018c). In optimally kneaded or fully developed dough, protein films or sheets are the predominant structural element (Delcour et al., 2012). At dry heat treatment above $50{ }^{\circ} \mathrm{C}$, unfolding of gluten proteins occurs. The hydrophobic parts of the protein molecules are getting more exposed, so that the rearrangement of disulphide bonds is favoured. As a result, gluten aggregates are forming, with decreased extractability and modified molecular weight distribution (Delcour et al., 2012). Therefore, a stronger dough or more stable foam can be produced. Schober et al. (2011) suggested that hydrophobic interactions rather than disulphide bonds are responsible for the gluten-like functionality of zein and kafirin, ascribing a key importance to non-covalent bonds in the protein aggregation of nongluten forming matrices.

In this work, the influence of HMT and flour hydration (dough yield) on the restoration of dough viscoelasticity of diluted binary wheat/non-wheat matrices was investigated by applying fundamental and empirical rheological procedures, and the protein structural reorganisation was monitored by measuring residual protein solubility in different media, and by assessing the accessibility of thiol groups inside the protein network. The correlation of protein structural parameters with the physic-chemical and rheological characteristics of the composite matrices were also studied, and significant relationships were established and discussed with regard to the thermal treatment and water availability in binary systems.

\section{Materials and methods}




\subsection{Materials}

Commercial flours from wheat (WT), chestnut $(\mathrm{CN})$, chickpea (CP), millets (MI) and teff (T) were purchased from Navarro (Spain). Refined WT (70\% extraction rate) of $195 \times 10^{-4} \mathrm{~J}$ energy of deformation $\mathrm{W}, 0.57$ curve configuration ratio $\mathrm{P} / \mathrm{L}$, and $58.8 \%$ water absorption in Brabender Farinograph, was used. Moisture, protein, ash and fat contents of commercial flours were determined following the ICC Standard methods 110/1, 105/2, 104/1, and 136, respectively (ICC 1976-1996). Soluble, insoluble and total fibre contents were determined according to the AOAC method 991.43 (Table 1). Two replicates were made for each flour analysis. Digestible carbohydrates were calculated by difference. Digestible carbohydrates were calculated by indirect determination as $100-[$ moisture + protein + fat + dietary fibre] (FAO 2003).

\subsection{Methods}

\subsubsection{Heat-moisture treatment (HMT)}

HMT conditions $\left(15 \%\right.$ moisture content, $1 \mathrm{~h}$ and $\left.120^{\circ} \mathrm{C}\right)$ were selected based on previous experiments (Collar and Armero, 2018a), in which maximization of viscometric profile during pasting and gelling and minimization of loss of hydration properties of flour samples were applied as criteria from conditions of total mixture reached $15 \%, 25 \%$, and $35 \%$, and heat kept for 1,3 , or $5 \mathrm{~h}$ at $120^{\circ} \mathrm{C}$ in a convection oven. Single CN, CP, MI and T flour samples were placed into screw-capped cylindrical glass containers ( $150 \mathrm{~mm}$ diameter, $250 \mathrm{~mm}$ height). Small amount of distilled water was added slowly with frequent stirring until moisture levels $(\mathrm{w} / \mathrm{w})$ of the total mixture reached $15 \%$, and equilibrated for $24 \mathrm{~h}$ at room temperature. Hydrated samples that occupied $13 \mathrm{~mm}$ height in containers were kept for 1 $\mathrm{h}$ at $120^{\circ} \mathrm{C}$ in a convection oven (P-Selecta, Barcelona, Spain). Samples took 20 min to reach the preset temperature, and $30 \mathrm{~min}$ to reach the room temperature after heating. Untreated native flours were used as controls. Untreated (-) and HMT (+) single flours were used in binary blends in presence of WTfor dough making.

\subsubsection{Visco-metric properties}

Pasting profiles (gelatinisation, pasting, and setback properties) of hydrated untreated and HMT treated binary blended flours prepared by WT- replacement with MI+ or T+, (30\%), and with $\mathrm{CN}+$ or $\mathrm{CP}+$ (10\%), were obtained with a Rapid Visco Analyser (RVA-4, Newport Scientific, Warriewood, Australia) using the ICC Standard method 162. Viscometric parameters were calculated from the pasting curve (Figure 1) using Thermocline v. 2.2 software (Collar, 2003). The slurry was heated to $50 \mathrm{C}$ and stirred at $160 \mathrm{r} / \mathrm{min}$ for $10 \mathrm{~s}$ for thorough dispersion. The slurry was held at $50{ }^{\circ} \mathrm{C}$ for up to $1 \mathrm{~min}$, and then heated to $95{ }^{\circ} \mathrm{C}$ over $3 \min 42 \mathrm{~s}$ and held at $95^{\circ} \mathrm{C}$ for $2 \min 30 \mathrm{~s}$, and finally cooled to $50{ }^{\circ} \mathrm{C}$ over $3 \mathrm{~min} 48 \mathrm{~s}$, and held at $50{ }^{\circ} \mathrm{C}$ for $2 \mathrm{~min}$. The pasting temperature $\left({ }^{\circ} \mathrm{C}\right.$ ) (when viscosity first increases by at least $25 \mathrm{mPas}$ over a 20 -s period), peak time (when peak viscosity occurred), peak viscosity (maximum hot paste viscosity), holding strength or trough viscosity (minimum hot paste viscosity), breakdown (peak viscosity minus holding strength or trough viscosity), viscosity at $95{ }^{\circ} \mathrm{C}$ (viscosity attained at the beginning of the holding period during cooking), viscosity at the end of the $95{ }^{\circ} \mathrm{C}$ holding period, viscosity at $50^{\circ} \mathrm{C}$ (viscosity attained at the beginning of the holding period during cooling), final viscosity (end of test after cooling to $50{ }^{\circ} \mathrm{C}$ and holding at this temperature), setback (final viscosity minus peak viscosity), and total setback (final viscosity minus holding strength) were calculated from the pasting curve using Thermocline v. 2.2 software (Collar, 2003). For each viscometric measurement, 3 replicates were made. 


\subsubsection{Dough making}

Binary doughs were prepared from wheat-based blended flours by WT- replacement with MI+ or T+, (30\%), and with $\mathrm{CN}+$ or $\mathrm{CP}+(10 \%)$, and incorporation of water (\%, flour basis) according to different hydration levels DY: low L (65\% CN, CP, MI; 80\% T), medium M (70\% CN, CP, MI; 90\% T) and high H (75\% CN, CP, MI; 100\% T). Binary untreated samples (-) were made at M hydration level for comparative purposes. Sampling resulted in 16 runs. A dough sample code was set referring to native () and HMT (+) CN, CP, MI and T flours hydrated at L, M and $\mathrm{H}$ levels in sample formulation, as follows: $\mathrm{CN}+\mathrm{L}, \mathrm{CN}+\mathrm{M}, \mathrm{CN}+\mathrm{H}, \mathrm{CN}-\mathrm{M}, \mathrm{CP}+\mathrm{L}, \mathrm{CP}+\mathrm{M}, \mathrm{CP}+\mathrm{H}, \mathrm{CP}-\mathrm{M}, \mathrm{MI}+\mathrm{L}, \mathrm{MI}+\mathrm{M}, \mathrm{MI}+\mathrm{H}, \mathrm{MI}-\mathrm{M}, \mathrm{T}+\mathrm{L}, \mathrm{T}+\mathrm{M}$, $\mathrm{T}+\mathrm{H}, \mathrm{T}-\mathrm{M}$ (Table 2). Blended flours (100 g), water (adapted $\%$, flour basis), and salt (2\%, flour basis were mixed in a $2 \mathrm{~kg}$ mixer at 60 revolutions $\mathrm{min}^{-1}$ for 10-13 min up to optimum dough development. Two trials were conducted per formulation. Preliminary tests were performed to know the range of hydration per formulation to avoid stickiness and deleterious effects on dough machinability. Preliminary tests for maximization of single non-wheat flour replacement of wheat flour showed the optimal amounts to be used without compromising dough machinability and handling ability were flourdependent. Amounts greater than $30 \%$ of cereal flours and $10 \%$ of non-cereal flours resulted in highly sticky doughs with low machinability (low cohesiveness and great firmness) and poor breadmaking performance of the blends. Analogously, previous tests conducted to know the amount of water necessary to avoid stickiness and deleterious effects on dough machinability proved that the range of $65-75 \%$ of water absorption was suitable for all the formulations except for teff formulated matrices $(80-100 \%)$ to assure dough handling ability during processing. Teff flour needs higher hydration in dough-making to avoid excessive dough hardness and stickiness.

\subsubsection{Oscillatory tests}

Dynamic oscillatory tests of the doughs were carried out with a Kinexus Pro+ rheometer (Malvern Instruments Ltd, Malvern, UK) with parallel plate geometry (40 mm diameter) of serrated surface and with $1 \mathrm{~mm}$ gap. The dough was placed between the plates, the surplus of sample was removed, and it was rested for $5 \mathrm{~min}$ to allow relaxation and to stabilize temperature at $25^{\circ} \mathrm{C}$. A cover-hood was placed over the sample to avoid sample dryness during the test. Temperature was established by means of a Peltier device (KNX2002) and a heat exchanger (KNX2500) (Marven Instruments Ltd., Marven, UK). Frequency sweeps were carried out from 10 to $1 \mathrm{~Hz}$ in the linear viscoelastic region (at a constant strain of $0.03 \%$ ). Frequency sweep data were fitted to the power law model as described in previous works (Ronda et al., 2013):

$$
\begin{gathered}
G^{\prime}(w)=G^{\prime}{ }_{1} \cdot w^{a} \\
G^{\prime \prime}(w)=G^{\prime \prime}{ }_{1} \cdot w^{b} \\
\tan \delta(w)=\frac{G^{\prime \prime}(w)}{G^{\prime}(w)}=\left(\frac{G^{\prime \prime}}{G^{\prime}}\right)_{1} \cdot w^{(b-a)}=(\tan \delta)_{1} \cdot w^{c}
\end{gathered}
$$

The coefficients $G{ }_{1}{ }_{1}, G{ }^{\prime}{ }_{1}$, and $(\tan \delta)_{1}$, represent the elastic and viscous moduli and the loss tangent at a frequency of $1 \mathrm{~Hz}$. Fittings were done in the frequency range $(1-10 \mathrm{~Hz})$, where a linear double logarithm curve was systematically obtained. The $a, b$ and $c$ exponents quantify the dependence degree of dynamic moduli and the loss tangent with the oscillation frequency, $\omega$. These tests were carried out in duplicate.

Strain sweeps were carried out from 0.01 to $100 \%$ at constant frequency of $1 \mathrm{~Hz}$. From the curves, the maximum strain/stress beyond which the dough structure was broken, $\gamma_{\max } / \tau_{\max }$, was calculated as the 
strain/stress at which the elastic modulus of the gels dropped with strain $10 \%$ with respect to the value obtained in the LVR. The shear strain $\left(\gamma_{\mathrm{cp}}\right)$ and stress $\left(\tau_{\mathrm{cp}}\right)$ of the crossing point, where $\mathrm{G}^{\prime}=\mathrm{G}^{\prime}$ ' were also recorded. These tests were carried out in duplicate.

\subsubsection{Protein analysis}

Water- and salt-soluble proteins were extracted by using phosphate buffer containing $0.05 \mathrm{M} \mathrm{NaH}_{2} \mathrm{PO}_{4}$ and $0.1 \mathrm{M} \mathrm{NaCl}, \mathrm{pH} 7.0$ (buffer P). Urea-soluble proteins were extracted using buffer $\mathrm{P}$ with the addition of $6 \mathrm{M}$ urea (buffer U). Finally, disulphide bonds were reduced by adding $0.1 \mathrm{M}$ dithiothreitol (DTT) to the buffer U (buffer D). Proteins were extracted from $50 \mathrm{mg}$ of freeze-dried dough dissolved in $1 \mathrm{ml}$ of each buffer as previously described by Alamprese et al (2005). Samples were incubated at $25^{\circ} \mathrm{C}$ for 3.5 $\mathrm{h}$ under stirring. After centrifugation at $12,000 \mathrm{~g}$ for $1 \mathrm{~h}$, the amount of extracted proteins present in the supernatants was determined according to Bradford protocol (Kruger, 2002), using bovine serum albumin as standard.

\subsubsection{Free thiols}

Free thiols (FT) were determined in protein extracts P, U and D using 25-100 $\mu \mathrm{L}$ aliquots (at least 2 nmol of protein). The procedure is based on the reaction of the thiol with Ellman's reagent 5,5'-dithiobis (2-nitrobenzoic acid) (DTNB) to give the mixed disulphide and 2-nitro-5-thiobenzoic acid (TNB) which is quantified by the absorbance of the anion $\left(\mathrm{TNB}_{2}^{-}\right)$at $412 \mathrm{~nm}$ (Aitken and Learmonth, 2009). FT from low molecular weight (LMW) proteins were estimated in P extracts, FT from high molecular weight (HMW) proteins were estimated in U-P extracts, and accessible thiol content from reduced disulphide bonds were estimated in D-U extracts after subtracting the contribution of buffer D $(10 \mu \mathrm{mol} \mathrm{FT/100}$ $\mu \mathrm{L})$.

\subsubsection{Statistical analysis}

Univariate ANOVA and multivariate MANOVA analysis of data (mean comparison of samples LSD) were performed by using Statgraphics V.7.1 program (Bitstream, Cambridge, MN).

\section{Results and Discussion}

A physicochemical approach was adopted to assess the effectiveness of HMT treatment and DY on the viscometric and viscoelastic behavior, and on the protein structure of composite doughs. Viscometric profile, dynamic rheological behavior, and protein aggregation/disaggregation were measured to quantify significant differences among samples.

\subsection{Visco-metric profile of native and HMT binary doughs}

Heat-induced gelatinization process solubilizes amylose and amylopectin molecules (composing a continuous phase) and granule remnants (composing dispersed phases), both of which are responsible for the rheological and textural properties of the starch paste (Kim et al. 2012).

Quantitative viscosity profiles of native and HMT hydrated binary blended flours of WT with MI, T, $\mathrm{CP}$, and $\mathrm{CN}$ were lower during both cooking and cooling cycles as compared to those of hydrated WT flour counterparts (Fig. 1). The RVA profile of binary blends of WT and non-WT flours was characterized by the presence of one maximum in the $95{ }^{\circ} \mathrm{C}$ holding period representing starch gelatinization under a constant shear, smaller breakdown of viscosity at the holding period, and a variable typical increase in setback viscosity on cooling varying from discrete $(\mathrm{T}, \mathrm{CP}$, and $\mathrm{CN})$, to prominent (MI) changes ascribed to the variable reassociation of constituent starch molecules, mainly amylose, into a more ordered state (Fig. 1). 
2 Table 1. Chemical and nutritional characteristics of native and heat-moisture-treated (HMT) wheat, teff, millet, chestnut, and chickpea flours

\begin{tabular}{|c|c|c|c|c|c|c|c|c|c|c|}
\hline \multirow{2}{*}{$\begin{array}{l}\text { Property }^{\mathrm{a}} \\
\%, \mathrm{~d} \text { b. }\end{array}$} & \multicolumn{2}{|c|}{ Wheat } & \multicolumn{2}{|c|}{ Teff } & \multicolumn{2}{|c|}{ Millet } & \multicolumn{2}{|c|}{ Chestnut } & \multicolumn{2}{|c|}{ Chickpea } \\
\hline & Native & HMT & Native & HMT & Native & HMT & Native & HMT & Native & HMT \\
\hline Moisture & $14.30 \pm 0.12 \mathrm{~d}$ & $15.12 \pm 0.11 \mathrm{e}$ & $12.62 \pm 0.13 \mathrm{c}$ & $14.95 \pm 0.21 \mathrm{e}$ & $11.60 \pm 0.09 b$ & $15.06 \pm 0.23 \mathrm{e}$ & $6.90 \pm 0.05 \mathrm{a}$ & $14.87 \pm 0.33 \mathrm{e}$ & $11.88 \pm 0.09 b$ & $15.22 \pm 0.09 \mathrm{e}$ \\
\hline Protein & $14.12 \pm 0.28 \mathrm{c}$ & $13.94 \pm 0.21 \mathrm{c}$ & $14.08 \pm 0.46 c$ & $13.96 \pm 0.56 c$ & $10.29 \pm 0.34 \mathrm{c}$ & $10.51 \pm 0.32 b$ & $6.44 \pm 0.20 \mathrm{a}$ & $6.56 \pm 0.34 \mathrm{a}$ & $18.82 \pm 0.60 \mathrm{~d}$ & $18.03 \pm 0.51 \mathrm{~d}$ \\
\hline Fat & $1.56 \pm 0.11 \mathrm{a}$ & $1.62 \pm 0.13 \mathrm{a}$ & $4.69 \pm 0.29 b c$ & $4.79 \pm 0.49 c$ & $4.03 \pm 0.39 b$ & $4.19 \pm 0.25 b$ & $4.08 \pm 0.18 b$ & $4.21 \pm 0.31 b c$ & $6.96 \pm 0.12 d$ & $7.41 \pm 0.31 \mathrm{e}$ \\
\hline $\begin{array}{l}\text { Digestible } \\
\text { carbohydrates }\end{array}$ & $81.70 \pm 2.30 c$ & $81.77 \pm 2.51 \mathrm{c}$ & $68.70 \pm 4.50 b$ & $69.26 \pm 6.10 b$ & $66.52 \pm 5.09 b$ & $66.29 \pm 6.24 b$ & $79.50 \pm 3.20 \mathrm{c}$ & $80.00 \pm 4.30 \mathrm{c}$ & $48.80 \pm 1.10 \mathrm{a}$ & $50.30 \pm 1.90 \mathrm{a}$ \\
\hline $\begin{array}{l}\text { Total dietary } \\
\text { fiber }\end{array}$ & $2.56 \pm 0.23 \mathrm{a}$ & $2.67 \pm 0.35 \mathrm{a}$ & $12.31 \pm 1.42 \mathrm{c}$ & $11.99 \pm 1.70 \mathrm{c}$ & $19.23 \pm 2.31 \mathrm{~d}$ & $19.01 \pm 1.96 \mathrm{~d}$ & $9.67 \pm 1.03 b$ & $9.23 \pm 1.43 b$ & $25.13 \pm 2.33 \mathrm{e}$ & $24.75 \pm 3.20 \mathrm{e}$ \\
\hline $\begin{array}{l}\text { Soluble dietary } \\
\text { fiber }\end{array}$ & $1.06 \pm 0.11 \mathrm{a}$ & $0.96 \pm 0.21 \mathrm{a}$ & $4.84 \pm 0.55 b$ & $4.96 \pm 0.66 b$ & $4.07 \pm 0.63 b$ & $3.98 \pm 0.59 b$ & - & - & $6.55 \pm 0.42 \mathrm{c}$ & $6.39 \pm 0.65 c$ \\
\hline $\begin{array}{l}\text { Insoluble } \\
\text { dietary fiber }\end{array}$ & $1.49 \pm 0.28 \mathrm{a}$ & $1.71 \pm 0.33 \mathrm{a}$ & $7.46 \pm 1.10 \mathrm{~b}$ & $7.03 \pm 1.23 b$ & $15.16 \pm 1.96 \mathrm{c}$ & $15.03 \pm 1.79 \mathrm{c}$ & - & - & $18.62 \pm 1.40 \mathrm{c}$ & $18.36 \pm 2.10 \mathrm{c}$ \\
\hline
\end{tabular}

3 Mean values \pm standard deviation

$4 \quad{ }^{a}$ Within rows, mean values with different following letter do differ significantly from each other $(\mathrm{p}<0.05)$

5 
On the opposite, qualitative RVA profile of WT flour clearly defined a maximum viscosity during the holding period (3777 $\mathrm{mPa} \mathrm{s}$ ), and a subsequent breakdown on cooking (1231 $\mathrm{mPa}$ ), followed by a discreet setback on cooling (2141 mPa s), as reported earlier (Collar 2003, 2017).

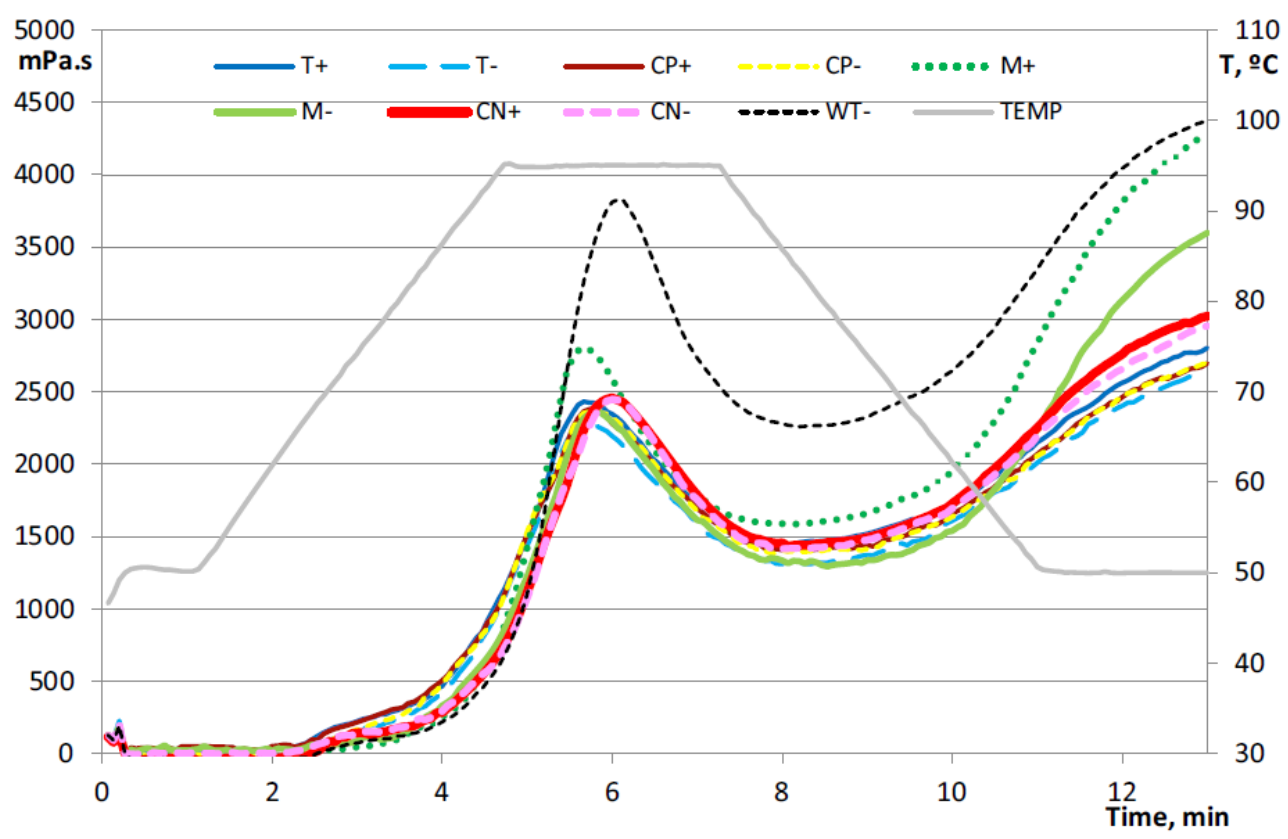

Fig. 1. Rapid Visco Analyzer profiles of native (-) and heat-moisture-treated (+) doughs from chestnut $(\mathrm{CN})$, chickpea (CP), millets (MI), and teff (T) binary blended flours with native wheat flour (WT).

RVA profiles for untreated and HMT hydrated blended flours exhibited some quantitative differences (Fig. 1), de- pending on both the non-wheat flour considered and the ther- mal treatment applied. In general, MI batters develop higher viscometric profiles during pasting and particularly during gelling $(\mathrm{p}$ $<0.05$ ) than the other flour batters provide (Fig. 1). During the cooking cycle, mean values for viscosity of MI vs CP/CN/T were as follows: peak viscosity (2534 mPa s vs $2315-2426 \mathrm{mPa}$ s), holding strength (1412 vs 1351-1414 mPa s), and breakdown (1122 mPa s vs 964-1102 mPa s). During cooling cycle, gelling characteristics (mean values) of MI vs CP/CN/T varied from 2459 to $1290-1535 \mathrm{mPa}$ s (total setback), from 2583 to $2064-2225 \mathrm{mPa}$ s (viscosity at $50{ }^{\circ} \mathrm{C}$ ), and from 3871 to $2647-2949 \mathrm{mPa}$ s (final viscosity), respectively. Despite HMT sig- nificantly ( $\mathrm{p}<0.05)$ increased the magnitude of some cooking and cooling parameters, changes were discreet (5-9\%) except for MI batters (Fig. 1), specifically peak viscosity $(+16 \%)$, holding strength $(+24 \%)$, final viscosity $(+15 \%)$, and viscos- ity at $50{ }^{\circ} \mathrm{C}(+22 \%)$. Since no significant change was observed in the chemical and nutritional composition analysis (Table 1), the differences of pasting/gelling characteristics may be attributed to the changes in the structure, as noted earlier (Lim et al. 2003). Changes of HMT on pasting and flow properties were collectively attributed to changes in granular volume (decreases in wheat, potato and lentil starches, but increases in oat starch), which modifies the resistance of the granule to deformation and disintegration, the interactions between starch chains and the amylose leaching (Hoover 2010). In millet flours submitted to dry heating, similar findings have been reported (Sun et al. 2014), suggesting that an ester bond could be formed when the starch and non-starch components were dry heated, similar to the interaction of starch and gum crosslinking during dry heating treatments (Lim et al. 2003). After dry heat, flour granules formed into big lumps under microscopy observation, and the gel structure of the 
flour had more compact holes and it had formed into a stronger and closer structure The denser structure of the dry heat sample gels illustrated that the dry heating process made the interactions stronger in the flour/starch compositions, providing functionality that is equivalent to chemical crosslinking (Sun et al. 2014). In hydrothermal treatments such as HMT, crosslinking effects are not so favored due to water mobility, despite the high amount of dietary fiber (19\%) present in millet flour (Table 1) can induce polymeric association with the polysaccharide functional groups in the starch after HMT at low moisture levels of $15 \%$.

Table 2. Sample code of native and heat-moisture-treated (HMT) binary matrices

\begin{tabular}{|c|c|c|c|c|c|}
\hline \multirow[t]{3}{*}{ Sample code } & \multirow[t]{3}{*}{$\begin{array}{l}\text { Wheat flour } \\
\text { replacement, \% }\end{array}$} & \multicolumn{4}{|c|}{ Hydration level, \% } \\
\hline & & Native (-) & & HMT (+) & \\
\hline & & Medium (M) & Low (L) & Medium (M) & High $(\mathrm{H})$ \\
\hline Chestnut (CN) & 10 & & & & \\
\hline $\mathrm{CN}+\mathrm{L}$ & & & 65 & & \\
\hline $\mathrm{CN}+\mathrm{M}$ & & & & 70 & \\
\hline $\mathrm{CN}+\mathrm{H}$ & & & & & 75 \\
\hline $\mathrm{CN}-\mathrm{M}$ & & 70 & & & \\
\hline Chickpea (CP) & 10 & & & & \\
\hline $\mathrm{CP}+\mathrm{L}$ & & & 65 & & \\
\hline $\mathrm{CP}+\mathrm{M}$ & & & & 70 & \\
\hline $\mathrm{CP}+\mathrm{H}$ & & & & & 75 \\
\hline $\mathrm{CP}-\mathrm{M}$ & & 70 & & & \\
\hline Millet (MI) & 30 & & & & \\
\hline $\mathrm{MI}+\mathrm{L}$ & & & 65 & & \\
\hline $\mathrm{MI}+\mathrm{M}$ & & & & 70 & \\
\hline $\mathrm{MI}+\mathrm{H}$ & & & & & 75 \\
\hline MI - M & & 70 & & & \\
\hline Teff (T) & 30 & & & & \\
\hline $\mathrm{T}+\mathrm{L}$ & & & 80 & & \\
\hline $\mathrm{T}+\mathrm{M}$ & & & & 90 & \\
\hline $\mathrm{T}+\mathrm{H}$ & & & & & 100 \\
\hline $\mathrm{T}-\mathrm{M}$ & & 90 & & & \\
\hline
\end{tabular}

\subsection{Fundamental rheological properties of native and HMT binary doughs}

Small deformation oscillatory measurements provide complementary information to large deformations using empirical methods in terms of structure of the material.

\subsubsection{Frequency sweeps}

The profiles of mechanical spectra for native and HMT blended doughs showed variable structured systems. The spectra exhibited a dependence of the viscoelastic moduli on oscillatory frequency in terms of increase of both moduli G' and G" with the increase in frequency $(1-10 \mathrm{~Hz})$, associated to a high overall chain mobility within the network (Lopes-da-Silva et al. 2007). The $a, b$, and $c$ exponents quantify the dependence degree of dynamic moduli and the loss tangent respectively with the oscillation frequency. Values ranged from 0.1251 to $0.2262(a), 0.2199$ to $0.2808(b)$, and 0.0488 to $0.1049(c)$. In good accordance, the frequency sweep data showed that all dough matrices displayed higher G', G', and $\tan \delta$ at higher frequencies compared to those at low frequencies, indicating the predominance of viscous characteristics in the dough and decrease in the elastic characteristics at higher frequencies. G' 
was greater than G" at all the frequencies studied $(1-10 \mathrm{~Hz})$, indicating viscoelastic soft solid nature of matrices (data not shown) and predominance of elastic character regardless the non-wheat flour used and the dough hydration applied in dough making. In good accordance, the frequency sweep data showed that G' values were greater than G" at all the frequencies studied $(1-10 \mathrm{~Hz})$, indicating the predominance of elastic character regardless the non-wheat flour used and the dough hydration applied in dough making. A viscoelastic soft solid nature of matrices can be concluded from the $\tan \delta$ values obtained that ranged $0.20-0.36$. In addition, all dough matrices displayed higher G', G', and $\tan \delta$ at higher frequencies compared to those at low frequencies. However, the viscous moduli showed always higher frequency dependence than elastic moduli, with "b" exponent values $(0.22-0.28)$ always above the "a" exponent values $(0.13-0.23)$. These results indicate a decrease in the solid-like characteristic predominance in doughs and the relative increase in the viscous behavior at higher frequencies. The coefficients $G^{\prime}{ }_{1}, G{ }^{\prime}$, and $(\tan \delta)_{1}$ represent the elastic and viscous moduli and the loss tangent at a frequency of $1 \mathrm{~Hz}$ (Table 3), respectively. For HMT blended samples, storage moduli values $\left(\mathrm{G}_{1}{ }_{1}\right)$ varied from 4050 to $17,823 \mathrm{~Pa}$, loss moduli $\left(\mathrm{G}{ }^{\prime}{ }_{1}\right)$ ranged from 809 to $4555 \mathrm{~Pa}$, and loss tangent $(\tan \delta)_{1}$ as the ratio of viscous and elastic response of the material being tested ranked from 0.1997 to 0.3614 (Table 3 ). The lower $(\tan \delta)_{1}$ values are indicative of a more elastic structure, hence, blends with cereal flours $\mathrm{T}+(0.2097-0.1997)$ and MI+ (0.2555-0.2581) exhibited the highest elasticity range at small deformations compared to non-cereal flours $\mathrm{CP}+(0.3614-0.3508)$ and $\mathrm{CN}+(0.3217-0.3014)$. Native blended samples made at intermediate $(\mathrm{M})$ hydration level presented compared to their HMT blended counterparts (Table 3), lower viscoelastic moduli values in non-wheat cereal flour blends $(-14-17 \%$ T-M, - 27-28\% MI-M) but higher dynamic moduli values in non-cereal flour blends (9-11\% CP-M, $37-41 \% \mathrm{CN}-\mathrm{M})$. The mentioned behavior is consistent with a more structured nature of cereal blends after HMT, particularly for MI+ samples. HMT allows control of molecular mobility at high temperatures by limiting the amount of water. HMT-induced changes in starch structure and properties have been found to vary with starch source and amylose content. For instance, tuber starches are more sensitive to HMT than legume or cereal starches (Gunaratne and Hoover 2002).

The different effect of HMT on cereal than non-cereal flour blends may be related to the different granular and crystalline structure of cereal starches (A-type X-ray pattern) versus non-cereal (mainly Ctype X-ray pattern) (Hoover 2010). Cereal starches did not exhibit an altered X-ray diffraction pattern after HMT (Jacobs and Delcour 1998). Also, the marked different nature and content of proteins, mainly insoluble storage proteins in cereals and predominantly soluble globulins and albumins in non-cereals flours, affect the impact of HMT on both flour proteins and starch-protein interactions.

Single and interactive effects of the type of non-wheat flour and the level of hydration in HMT blends were significant $(\mathrm{p}<0.05)$ on main fundamental rheological parameters (Table 4). Effects of flour type are particularly significant for G' 1 and $(\tan \delta) 1$. Higher G'1 and lower $(\tan \delta) 1$ values were observed for non-wheat cereal flour blends (10358-11,074 Pa, 0.2033-0.2545) as compared with non-cereal flour blends (6880-7947 Pa, 0.3556-0.3190). Flour hydration systematically induced a stepped decrease of $40-43 \%$ in dynamic moduli values from $\mathrm{L}$ to $\mathrm{M}$ and from $\mathrm{M}$ to $\mathrm{H}$ blended doughs. The larger drops in dynamic moduli were noticed in cereal blends at highest level of flour hydration $(\mathrm{H})$, reaching values of 4050 (G'1) and $810 \mathrm{~Pa}\left(\mathrm{G}^{\prime} 1\right)$ for T and 5122 (G'1) and $1323 \mathrm{~Pa}\left(\mathrm{G}^{\prime} 1\right)$ for MI (Table 4). On the contrary, cereal blends made at lower level of hydration (L) showed the greatest values for dynamic moduli, particularly for G'1 (> 17,700 Pa), in accordance with a more solid and structured nature. 
Table 3. Fundamental rheological parameters of native (-) and heat-moisture-treated (+) doughs from chestnut (CN), chickpea (CP), millets (MI), and teff (T) blended wheat flours made at low $(\mathrm{L})$, medium $(\mathrm{M})$, and high $(\mathrm{H})$ hydration levels

\begin{tabular}{|c|c|c|c|c|c|c|c|}
\hline \multirow[t]{2}{*}{ Sample } & \multicolumn{3}{|c|}{ Frequency sweeps } & \multicolumn{4}{|c|}{ Stress/strain sweeps } \\
\hline & $G_{1}^{\prime}, \mathrm{Pa}$ & $G^{\prime \prime}{ }_{1}, \mathrm{~Pa}$ & $(\tan \delta)_{1}$ & $\gamma_{\text {cp }}\left(G^{\prime}=G^{\prime \prime}\right), \%$ & $\tau_{\text {cp }}\left(G^{\prime}=G^{\prime \prime}\right), \mathrm{Pa}$ & $\gamma_{\max }, \%$ & $\tau_{\max }, \mathrm{Pa}$ \\
\hline $\mathrm{T}-\mathrm{M}$ & $7975 \pm 78 b$ & $1587 \pm 27 b$ & $0.1990 \pm 0.0014 a$ & $97.36 \pm 3.73 \mathrm{ab}$ & $485 \pm 2 b$ & $0.1263 \pm 0.0000 \mathrm{a}$ & $9.08 \pm 0.06 b$ \\
\hline $\mathrm{T}+\mathrm{L}$ & $17,763 \pm 6 d$ & $3725 \pm 56 d$ & $0.2097 \pm 0.0030 b$ & $100.00 \pm 0.00 b$ & $1292 \pm 24 d$ & $0.1295 \pm 0.0411 \mathrm{a}$ & $17.84 \pm 4.38 \mathrm{~d}$ \\
\hline $\mathrm{T}+\mathrm{M}$ & $9260 \pm 158 c$ & $1856 \pm 62 c$ & $0.2005 \pm 0.0033 a$ & $90.97 \pm 6.39 a$ & $557 \pm 12 c$ & $0.1414 \pm 0.0226 \mathrm{a}$ & $10.61 \pm 0.02 c$ \\
\hline $\mathrm{T}+\mathrm{H}$ & $4050 \pm 150 a$ & $809 \pm 75 a$ & $0.1997 \pm 0.0011 \mathrm{a}$ & $94.71 \pm 1.38 \mathrm{ab}$ & $224 \pm 43 a$ & $0.1258 \pm 0.0000 \mathrm{a}$ & $3.49 \pm 0.01 \mathrm{a}$ \\
\hline MI-M & $7476 \pm 233 b$ & $1847 \pm 79 b$ & $0.2470 \pm 0.0028 a$ & $71.31 \pm 3.02 b$ & $368 \pm 9 b$ & $0.0449 \pm 0.0070 \mathrm{a}$ & $2.71 \pm 0.32 \mathrm{a}$ \\
\hline $\mathrm{MI}+\mathrm{L}$ & $17,823 \pm 1076 d$ & $4555 \pm 246 d$ & $0.2555 \pm 0.0017 b$ & $85.78 \pm 6.65 c$ & $815 \pm 36 d$ & $0.0788 \pm 0.0000 \mathrm{~d}$ & $9.40 \pm 1.77 \mathrm{c}$ \\
\hline $\mathrm{MI}+\mathrm{M}$ & $10,278 \pm 363 c$ & $2569 \pm 66 c$ & $0.2500 \pm 0.0030 \mathrm{a}$ & $73.92 \pm 4.01 b$ & $472 \pm 23 c$ & $0.0635 \pm 0.0000 c$ & $4.96 \pm 0.01 b$ \\
\hline $\mathrm{MI}+\mathrm{H}$ & $5122 \pm 73 a$ & $1323 \pm 19 a$ & $0.2581 \pm 0.0004 c$ & $60.19 \pm 3.36 \mathrm{a}$ & $218 \pm 8 a$ & $0.0631 \pm 0.0000 \mathrm{~b}$ & $2.43 \pm 0.26 \mathrm{a}$ \\
\hline CP-M & $7261 \pm 154 b$ & $2526 \pm 91 b$ & $0.3478 \pm 0.0052 \mathrm{a}$ & $50.65 \pm 4.75 b$ & $320 \pm 2 c$ & $0.1258 \pm 0.0000 b$ & $7.01 \pm 0.33 b$ \\
\hline $\mathrm{CP}+\mathrm{L}$ & $9523 \pm 1103 c$ & $3439 \pm 372 c$ & $0.3614 \pm 0.0029 a$ & $45.65 \pm 1.27 \mathrm{a}$ & $419 \pm 41 d$ & $0.1264 \pm 0.0000 b$ & $10.21 \pm 2.29 c$ \\
\hline $\mathrm{CP}+\mathrm{M}$ & $6541 \pm 742 b$ & $2316 \pm 211 b$ & $0.3546 \pm 0.0079 a$ & $45.45 \pm 3.26 a b$ & $279 \pm 17 b$ & $0.1131 \pm 0.0181 \mathrm{a}$ & $7.03 \pm 0.64 b$ \\
\hline $\mathrm{CP}+\mathrm{H}$ & $4575 \pm 743 a$ & $1600 \pm 204 a$ & $0.3508 \pm 0.0124 a$ & $43.65 \pm 1.88 \mathrm{a}$ & $184 \pm 4 a$ & $0.1127 \pm 0.0184 a$ & $4.81 \pm 0.59 \mathrm{a}$ \\
\hline CN-M & $9944 \pm 2752 b c$ & $3201 \pm 899 c$ & $0.3217 \pm 0.0014 b$ & $55.01 \pm 6.85 \mathrm{ab}$ & $418 \pm 35 c$ & $0.1126 \pm 0.0203 \mathrm{ab}$ & $8.79 \pm 1.66 b$ \\
\hline $\mathrm{CN}+\mathrm{L}$ & $11,569 \pm 610 c$ & $3743 \pm 177 d$ & $0.3235 \pm 0.0019 b$ & $64.44 \pm 4.25 b$ & $585 \pm 56 d$ & $0.1261 \pm 0.0000 b$ & $12.68 \pm 1.19 \mathrm{c}$ \\
\hline $\mathrm{CN}+\mathrm{M}$ & $7050 \pm 227 b$ & $2340 \pm 15 b$ & $0.3321 \pm 0.0086 b$ & $51.12 \pm 3.53 \mathrm{a}$ & $334 \pm 7 b$ & $0.1289 \pm 0.0408 b$ & $8.26 \pm 1.09 b$ \\
\hline $\mathrm{CN}+\mathrm{H}$ & $5222 \pm 467 a$ & $1574 \pm 155 \mathrm{a}$ & $0.3014 \pm 0.0028 \mathrm{a}$ & $50.53 \pm 0.40 \mathrm{a}$ & $220 \pm 20 a$ & $0.1003 \pm 0.0000 \mathrm{a}$ & $4.01 \pm 0.35 \mathrm{a}$ \\
\hline
\end{tabular}

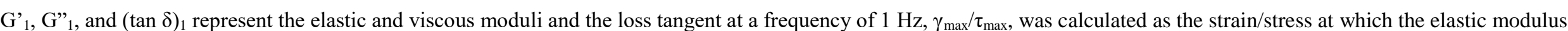

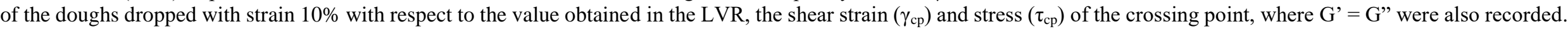

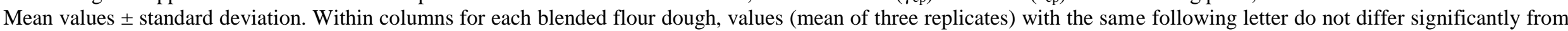
each other $(p>0.05)$. 
Table 4. Significant single and interactive effects of design factors (flour and hydration level) on the fundamental rheological parameters of heat-moisture-treated doughs from chestnut, chickpea, millets, and teff blended wheat flours made at low (L), medium (M), and high (H) hydration levels

\begin{tabular}{|c|c|c|c|c|c|c|c|c|c|c|c|c|c|c|c|c|c|c|c|}
\hline \multirow[t]{2}{*}{ Parameter } & \multirow[t]{2}{*}{ Unit } & \multirow{2}{*}{$\begin{array}{l}\text { Overall } \\
\text { mean }\end{array}$} & \multicolumn{4}{|l|}{ Flour } & \multicolumn{4}{|c|}{ Hydration } & \multicolumn{9}{|c|}{$2^{\text {nd }}-$ order interaction, flour $x$ hydration } \\
\hline & & & Level & $\mathrm{SE}$ & Mean & * & Level & SE & Mean & * & Level & $\begin{array}{l}\text { Teff } \mathrm{x} \\
\text { Hydration }\end{array}$ & * & $\begin{array}{l}\text { Millet } x \\
\text { Hydration }\end{array}$ & * & $\begin{array}{l}\text { Chickpea } x \\
\text { Hydration }\end{array}$ & * & $\begin{array}{l}\text { Chestnut } \mathrm{x} \\
\text { Hydration }\end{array}$ & * \\
\hline \multicolumn{20}{|l|}{$\begin{array}{r}\text { Frequency } \\
\text { sweeps }\end{array}$} \\
\hline \multirow[t]{4}{*}{$G_{1}^{\prime}$} & $\mathrm{Pa}$ & 9065 & Teff & 244 & 10,358 & $\mathrm{c}$ & $\mathrm{L}$ & 212 & 14,169 & $\mathrm{c}$ & Flour $\times \mathrm{L}$ & 17,763 & $\mathrm{e}$ & $17,822.5$ & e & 9523 & $\mathrm{c}$ & 11,569 & $\mathrm{~d}$ \\
\hline & & & Millet & & 11,074 & $\mathrm{c}$ & $\mathrm{M}$ & & 8282 & $\mathrm{~b}$ & Flour $\times M$ & 9260 & $\mathrm{c}$ & 10,278 & $\mathrm{c}$ & 6541 & $\mathrm{~b}$ & 7050.5 & $\mathrm{~b}$ \\
\hline & & & Chickpea & & 6880 & $\mathrm{a}$ & $\mathrm{H}$ & & 4742 & $\mathrm{a}$ & Flour $\times \mathrm{H}$ & 4050 & $\mathrm{a}$ & 5122 & a & 4575 & $\mathrm{a}$ & 5222 & $\mathrm{a}$ \\
\hline & & & Chestnut & & 7947 & $\mathrm{~b}$ & & & & & SE & 423 & & & & & & & \\
\hline \multirow[t]{4}{*}{$G_{1}^{\prime \prime}$} & $\mathrm{Pa}$ & 2488 & Teff & 70 & 2130 & $\mathrm{a}$ & $\mathrm{L}$ & 61 & 3865 & $\mathrm{c}$ & Flour $\times$ L & 3725 & $\mathrm{~d}$ & 4555 & e & 3439 & $\mathrm{~d}$ & 3743 & $\mathrm{~d}$ \\
\hline & & & Millet & & 2816 & $\mathrm{c}$ & $\mathrm{M}$ & & 2271 & $\mathrm{~b}$ & Flour $\times M$ & 1856 & $\mathrm{~b}$ & 2570 & $\mathrm{c}$ & 2317 & $\mathrm{c}$ & 2340 & $\mathrm{c}$ \\
\hline & & & Chickpea & & 2452 & $\mathrm{~b}$ & $\mathrm{H}$ & & 1327 & $\mathrm{a}$ & Flour $\times \mathrm{H}$ & 810 & $\mathrm{a}$ & 1323 & $\mathrm{~b}$ & 1601 & $\mathrm{~b}$ & 1575 & $\mathrm{~b}$ \\
\hline & & & Chestnut & & 2553 & $\mathrm{~b}$ & & & & & SE & 122 & & & & & & & \\
\hline \multirow{4}{*}{$\operatorname{Tan} \delta_{1}$} & & 0.2831 & Teff & 0.0025 & 0.2033 & $\mathrm{a}$ & $\mathrm{L}$ & 0.0022 & 0.2875 & $\mathrm{~b}$ & Flour $\times \mathrm{L}$ & 0.2097 & $\mathrm{a}$ & 0.2555 & $\mathrm{~b}$ & 0.3614 & $\mathrm{e}$ & 0.3235 & $\mathrm{~d}$ \\
\hline & & & Millet & & 0.2545 & $\mathrm{~b}$ & M & & 0.2843 & $\mathrm{~b}$ & Flour $\times M$ & 0.2005 & $\mathrm{a}$ & 0.2500 & $\mathrm{~b}$ & 0.3546 & $\mathrm{e}$ & 0.3321 & $\mathrm{~d}$ \\
\hline & & & Chickpea & & 0.3556 & d & $\mathrm{H}$ & & 0.2775 & $\mathrm{a}$ & Flour $\times \mathrm{H}$ & 0.1997 & $\mathrm{a}$ & 0.2581 & $\mathrm{~b}$ & 0.3508 & $\mathrm{e}$ & 0.3014 & $\mathrm{c}$ \\
\hline & & & Chestnut & & 0.319 & $\mathrm{c}$ & & & & & SE & 0.0044 & & & & & & & \\
\hline \multicolumn{20}{|l|}{$\begin{array}{l}\text { Stress/strain } \\
\text { sweeps }\end{array}$} \\
\hline \multirow{4}{*}{$\begin{array}{l}Y_{\text {cross-point }} \\
\quad\left(G^{\prime}=G^{\prime \prime}\right)\end{array}$} & $\%$ & 67.64 & Teff & 1.41 & 96.73 & $\mathrm{~d}$ & $\mathrm{~L}$ & 1.22 & 74.17 & $\mathrm{c}$ & Flour $\times \mathrm{L}$ & 100.00 & $\mathrm{e}$ & 85.79 & $\mathrm{~d}$ & 45.66 & $\mathrm{a}$ & 65.22 & $\mathrm{~b}$ \\
\hline & & & Millet & & 73.3 & $\mathrm{c}$ & M & & 66.49 & $\mathrm{~b}$ & Flour $\times M$ & 95.49 & $\mathrm{e}$ & 73.93 & $\mathrm{c}$ & 45.45 & $\mathrm{a}$ & 51.12 & $\mathrm{a}$ \\
\hline & & & Chickpea & & 44.92 & $\mathrm{a}$ & $\mathrm{H}$ & & 62.27 & $\mathrm{a}$ & Flour $\times \mathrm{H}$ & 94.71 & $\mathrm{e}$ & 60.19 & $\mathrm{~b}$ & 43.65 & $\mathrm{a}$ & 50.53 & $\mathrm{a}$ \\
\hline & & & Chestnut & & 55.62 & $\mathrm{~b}$ & & & & & SE & 2.45 & & & & & & & \\
\hline \multirow{4}{*}{$\begin{array}{l}\mathrm{T}_{\text {cross-point }} \\
\quad\left(G^{\prime}=G^{\prime \prime}\right)\end{array}$} & $\mathrm{Pa}$ & 467 & Teff & 44 & 964 & $\mathrm{c}$ & $\mathrm{L}$ & 38 & 778 & $\mathrm{c}$ & Flour $\times \mathrm{L}$ & 1292 & $\mathrm{e}$ & 815 & d & 419 & $a b c$ & 588 & bcd \\
\hline & & & Millet & & 502 & $\mathrm{~b}$ & M & & 413 & $\mathrm{~b}$ & Flour $\times M$ & 565 & $\mathrm{bc}$ & 472 & $\mathrm{bc}$ & 279 & $\mathrm{ab}$ & 334 & $a b$ \\
\hline & & & Chickpea & & 294 & $\mathrm{a}$ & $\mathrm{H}$ & & 211 & a & Flour $\times \mathrm{H}$ & 224 & $\mathrm{a}$ & 218 & $\mathrm{a}$ & 184 & $\mathrm{a}$ & 220 & $\mathrm{a}$ \\
\hline & & & Chestnut & & 381 & $a b$ & & & & & SE & 76 & & & & & & & \\
\hline \multirow[t]{4}{*}{$\mathrm{Y}_{\max }$} & $\%$ & 0.1091 & Teff & 0.0079 & 0.1322 & $\mathrm{~b}$ & $\mathrm{~L}$ & & $\mathrm{~ns}$ & & Flour $\times \mathrm{L}$ & $\mathrm{ns}$ & & $\mathrm{ns}$ & & $\mathrm{ns}$ & & $\mathrm{ns}$ & \\
\hline & & & Millet & & 0.0685 & $\mathrm{a}$ & M & & & & Flour $\times M$ & & & & & & & & \\
\hline & & & Chickpea & & 0.1174 & $\mathrm{~b}$ & $\mathrm{H}$ & & & & Flour $\times \mathrm{H}$ & & & & & & & & \\
\hline & & & Chestnut & & 0.1184 & $\mathrm{~b}$ & & & & & SE & & & & & & & & \\
\hline \multirow[t]{4}{*}{$T_{\max }$} & $\mathrm{Pa}$ & 7.98 & Teff & 0.66 & 10.64 & $\mathrm{c}$ & $\mathrm{L}$ & 0.57 & 12.53 & $\mathrm{c}$ & Flour $\times \mathrm{L}$ & $\mathrm{ns}$ & & $\mathrm{ns}$ & & $\mathrm{ns}$ & & $\mathrm{ns}$ & \\
\hline & & & Millet & & 5.6 & $\mathrm{a}$ & M & & 7.72 & $\mathrm{~b}$ & Flour $\times M$ & & & & & & & & \\
\hline & & & Chickpea & & 7.35 & $a b$ & $\mathrm{H}$ & & 3.68 & $\mathrm{a}$ & Flour $\times \mathrm{H}$ & & & & & & & & \\
\hline & & & Chestnut & & 8.32 & $\mathrm{~b}$ & & & & & SE & & & & & & & & \\
\hline
\end{tabular}

$G_{1}^{\prime}, G_{1}^{\prime \prime}$, and $(\tan \delta)_{1}$, represent the elastic and viscous moduli and the loss tangent at a frequency of $1 \mathrm{~Hz}, \mathrm{Y}_{\max } / \mathrm{T}_{\max }$, was calculated as the strain/stress at which the elastic modulus of the doughs dropped with strain $10 \%$ with respect to the value obtained in the LVR, the shear strain $\left(\mathrm{Y}_{\mathrm{cp}}\right)$ and stress $\left(\mathrm{T}_{\mathrm{cp}}\right)$ of the crossing point, where $G^{\prime}=G^{\prime \prime}$ were also recorded. $* p<0.05$. SE standard error 


\subsubsection{Stress/ strain sweeps}

Stress/strain sweeps provide the $\tau_{\max } / \gamma_{\max }$ values or maximum stress/strain that blends were able to tolerate before the structure collapsed (Table 3). The $\tau_{\max }$ values for all the doughs ranged from 2.43 $(\mathrm{MI}+\mathrm{H})$ to $17.84 \mathrm{~Pa}(\mathrm{~T}+\mathrm{L})$, while $\gamma_{\max }$ values varied from $0.0631(\mathrm{MI}+\mathrm{H})$ to $0.1414 \%(\mathrm{~T}+\mathrm{M})$. HMT blended samples made at intermediate $(\mathrm{M})$ hydration level presented compared to their native blended counterparts greater tolerance to stress/strain before losing the structure only in non-wheat cereal blends, while in non-cereal blends HMT effects were negligible (Table 4). In parallel, as expected the shear stress $\left(\tau_{\mathrm{cp}}\right)$ of the crossing point, where $\mathrm{G}^{\prime}=\mathrm{G}^{\prime}$ increased on HMT for T and MI blends, revealing a solid like elastic structure over higher shear stress. The type of non- wheat flour and the level of hydration in HMT blends significantly affected shear stress and strain maximum values (Table 4). T+ in blends provided the greatest values for $\tau_{\max }(10.64 \mathrm{~Pa}), \gamma_{\max }(0.1322 \%), \tau_{\mathrm{cp}}(964 \mathrm{~Pa}), \gamma_{\mathrm{cp}}(96.73 \%)$, while $\mathrm{CP}+$ gave the smallest values for $\tau_{\mathrm{cp}}(294 \mathrm{~Pa}), \gamma_{\mathrm{cp}}(44.92 \%)$, and $\mathrm{MI}+$ for $\tau_{\max }(5.6 \mathrm{~Pa}), \gamma_{\max }$ $(0.0685 \%)$. Increased flour hydration significantly weakened blends structure, evidenced by a relevant drop in both $\tau_{\mathrm{cp}}$ and $\tau_{\max }$ values up to $73 \%$ from $\mathrm{L}$ to $\mathrm{H}$ hydration levels (Table 4 ). A decrease in $\tau_{\mathrm{cp}}$ was particularly notable for non-wheat cereal matrices where the shift from elastic-like to viscous-like structure took place at lower shear stress.

\subsection{Impact of HMT and DY on protein aggregation/disaggregation of binary doughs}

The importance of intrinsic protein characteristics for protein network formation, either in absence of other proteins, in the presence of proteins derived from the same source, or in the presence of proteins from a different source has been stressed (Lambrecht et al. 2017). Different protein types impact each other during heat treatment. It has been stated that a positive co-protein effect occurs when heat-induced polymerization of a mixture of proteins takes place, being more intense than that of the isolated proteins. Protein solubility measurements provide more direct information about conformational changes of proteins due to the heat treatment. The protein extractability in dissociating media such as SDS (Wang et al. 2016) and urea (Angioloni and Collar 2013b) were good indicators of the degree of crosslinking. The level of accessible free SH groups and the surface hydrophobicity of unfolded proteins were the main protein characteristics determining co-protein effects in mixtures with gluten (Lambrecht et al. 2017). Protein aggregation can be impacted by both covalent (disulfide) and non-covalent bonds. The creation of new bonds favoring the protein network formation was recently shown to improve the baking performance of gluten-free flours (Renzetti et al. 2008; Angioloni and Collar 2013b; Collar and Angioloni 2017).

Binary doughs from single $\mathrm{T}+, \mathrm{MI}+, \mathrm{CP}+$, and $\mathrm{CN}+$ thermally treated flours blended with wheat flour were extracted according to their solubility in different buffers ( $\mathrm{P}, \mathrm{U}$, and $\mathrm{D})$, and the protein concentration was measured (Fig. 2). To understand the impact of HMT and flour hydration on proteins, proteins extracted from untreated batters at intermediate hydration level (M) were compared to those extracted from heat-treated batters at increasing hydration levels ( $\mathrm{L}, \mathrm{M}$, and $\mathrm{H})$. Overall, minor to null differences were observed in protein solubility ( $\mathrm{g} / 100 \mathrm{~g}$ flour, as is) in buffers $\mathrm{P}$ and $\mathrm{U}$ between native (1.07-1.84, 2.36-3.14) and HMT samples (1.03-2.43, 2.60-3.18) at M hydration level, except for CN samples $(-44 \%)$ in the extractability in buffer P (Fig. 2). On the contrary, protein solubility under reducing conditions (buffer D) increased with HMT (+10-15\%) except for T samples. Unlike phosphate 
buffer extractability for small amounts of HMT flour proteins (0.78-2.43 g), addition of urea increased the amount of extracted proteins (2.43-3.85 g), and further significant increase was observed when DTT was added to the buffer U (3.07-6.69 g) (Fig. 2).

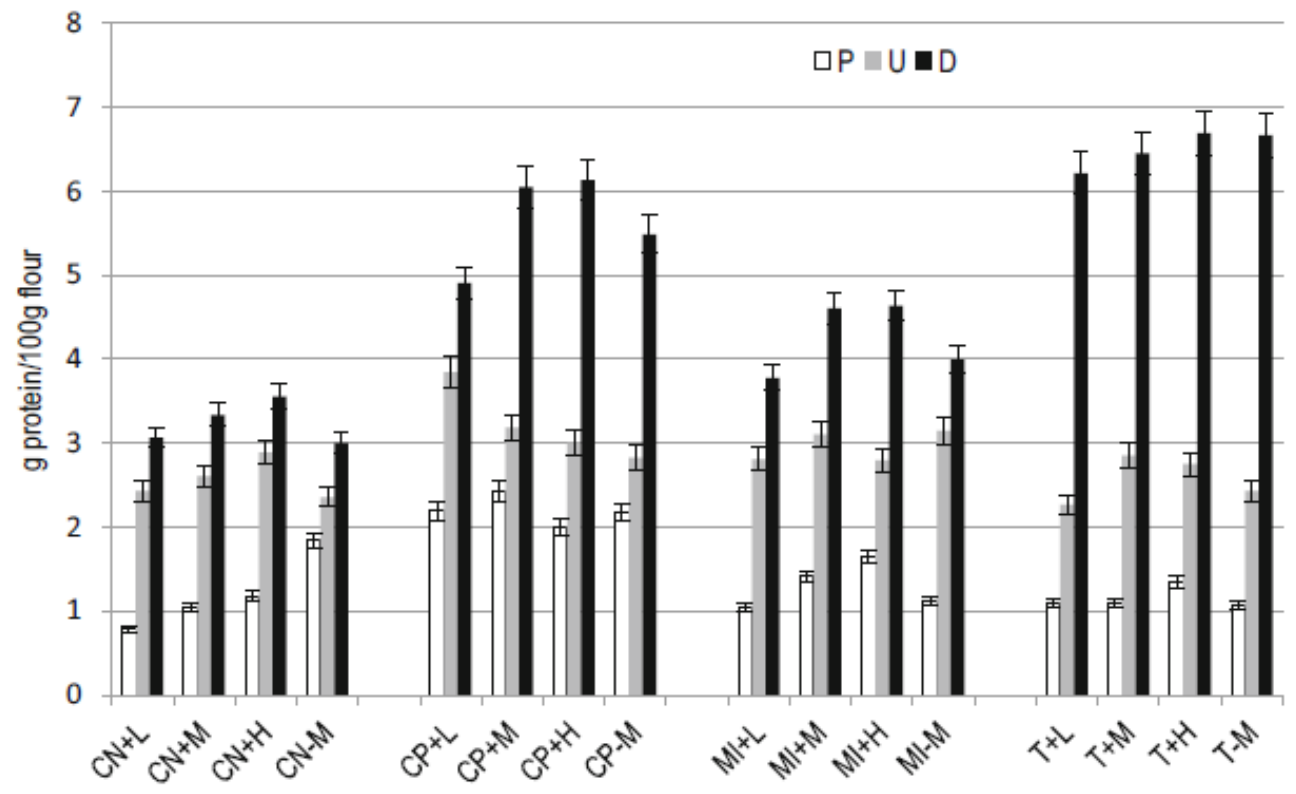

Fig. 2 Protein extractability in different solvents of native $(-)$ and heat-moisture-treated $(+)$ doughs from chestnut $(\mathrm{CN})$, chickpea $(\mathrm{CP})$, millets $(\mathrm{MI})$, and teff $(\mathrm{T})$ blended wheat flours made at low $(\mathrm{L})$, medium $(\mathrm{M})$, and high $(\mathrm{H})$ hydration levels. Water- and salt-soluble proteins were extracted by using phosphate buffer containing $0.05 \mathrm{M}$ $\mathrm{NaH} 2 \mathrm{PO} 4$ and $0.1 \mathrm{M} \mathrm{NaCl}, \mathrm{pH} 7.0$ (buffer P), urea-soluble proteins were extracted using buffer $\mathrm{P}$ with the addition of $6 \mathrm{M}$ urea (buffer $\mathrm{U}$ ), and disulphide bonds were reduced by adding $0.1 \mathrm{M}$ dithiothreitol to the buffer $\mathrm{U}$ (buffer D).

Data suggest the presence of quantifiable reticulation of $\mathrm{CN}, \mathrm{CP}$, and $\mathrm{MI}$ proteins by inter-protein covalent/disulphide bonds after HMT, but weak protein rearrangements after HMT in $\mathrm{T}$ proteins. Formation of inter and intra protein covalent bonds and new links with others flour components can be established. HMT treatment significantly reduced the amount of water and salt-soluble proteins extracted in phosphate buffer, for CN matrices particularly at lower hydration level (L). Reduced protein solubility in phosphate buffer suggests the creation of new non-covalent bonds, according to the results reported by Alamprese et al. (2005) for fresh egg pasta. In proso millet protein, the formation of hydrophobic aggregates during heating in water has been suggested, supported by an increase in surface hydrophobicity upon cooking (Gulati et al. 2017). There is a change in millet protein on heating which is potentially due to the exposure of tryptophans to aqueous phase due to opening of protein structure. Heat-moisture treatment had a major effect on sorghum protein solubility which may have been due to the formation of large, disulfide cross-linked polymers which had reduced solubility. The reduced solubility could also be due to denaturation and formation of other types of bonds not disrupted by the SDS buffer and reducing agents used for extraction (Vu et al. 2017). 
The hydration level does affect the concentration of extracted proteins depending on the thermally treated flour. Increase in DY from L, M, and $\mathrm{H}$ produced a significant and progressive promotion $(\mathrm{CN}+)$, decline $(\mathrm{CP}+)$, or no effect $(\mathrm{MI}+, \mathrm{T}+)$ in the amount of proteins extracted by urea-containing buffer with water availability. When DTT was added to the urea-containing buffer, an increasing trend in the protein solubility of all flours was observed with DY, particularly for CP+ flours that exhibited a net increase by $25 \%$ from $\mathrm{L}$ to $\mathrm{H}$ hydration level of doughs. Solubility in urea, along with the effects of the disulfidereducing agent, provides information about covalent and non-covalent interactions between intrinsically water-insoluble proteins (such as gliadins and glutelins in flour) and those proteins that may become water-insoluble upon thermal treatment. Protein insolubilization may be ascribed either to their denaturation/aggregation or because they become involved in interactions with other proteins. In fact, gluten/non-gluten-forming proteins from wheat flour are present in variable amounts in binary flour matrices, from $9.88 \%(\mathrm{MI}+, \mathrm{T}+)$ to $12.71 \%(\mathrm{CN}+, \mathrm{CP}+)$. Although legume proteins are generally low in methionine, cysteine, and tryptophan (Boye et al. 2010), it seems that disulfide bonds were formed on HMT, being crosslinking favored by the hydration level of dough during mixing (Fig. 2). Assuming that formation of disulfide bonds occurred, achieved results indicate that HMT may have promising effects on promoting structure formation of non-wheat flours through protein aggregation and covalent crosslinking, provided enough water is available.

Determination of accessible thiol content (TC) in protein extracts from total reduced disulfide bonds confirmed the crosslinking effect of HMT at intermediate DY (M), except for CP matrices, by significant promotion of TC by $70 \%(\mathrm{CN}), 150 \%(\mathrm{MI})$, and 66\% (T), respectively (Fig. 3a). DY significantly promoted the number of exposed -SH groups from intermolecular S-S bridges, being maximum values (mmols -SH/100 g flour) closely dependent on the hydration of HMT flour: $3.44(\mathrm{CN}+\mathrm{H}), 1.77(\mathrm{CP}+\mathrm{M})$, $4.59(\mathrm{MI}+\mathrm{H}), 3.83(\mathrm{~T}+\mathrm{M})$ (Fig. 3a). Polypeptides of teff prolamins of 36.1, 50.2, 66.2, and 90.0 kDa were reported as disulfide bonded. The lower polymerization, hydrophobicity, and denaturation temperature of teff prolamins probably make them somewhat functional in bread making (Adebowale et al. 2011).

Quantification of free thiols from Low (P extract) and high molecular weight (U-P extracts) proteins of native and HMT blended doughs made at low (L), medium (M), and high (H) hydration levels provided additional information on the dissociation of non-covalent aggregates of different molecular size (Fig. $3 b)$.

The number of exposed - $\mathrm{SH}$ groups was higher in the presence than in the absence of urea except for $\mathrm{T}$ blends, suggesting that protein denaturation of individual polypeptides and dissociation of non-covalent aggregates significantly led to an increase in the number of accessible thiols in CN, CP, and MI blends. HMT provided different impact on the amount of accessible thiols according to the non-wheat flour in the blend and the protein extract. In P-buffered saline solutions extracting water soluble protein components, an increase by $230 \%$ in $\mathrm{CN}$ and by $55 \%$ in MI, but a decrease by $42 \%$ in CP and by $8 \%$ in $\mathrm{T}$ were noticed. These trends were compatible with the formation of SH-containing water-soluble aggregates (CN, MI) and the formation of water-insoluble aggregates of higher molecular weight (CP, $\mathrm{T}$ ), on HMT. In fact, adding the dissociating agent urea to $\mathrm{P}$ buffered saline solutions led to exhaustive extraction of accessible thiols that underwent on HMT an increase in $\mathrm{CN}(8 \%), \mathrm{CP}(326 \%)$, and T (500\%) extracts and a decrease in MI (32\%). Increasing DY from L to H provided, in general, a decline 
in the extractability of free thiols in P extracts, particularly for $\mathrm{CN}(70 \%)$ and $\mathrm{T}(40 \%)$ and a promotion of exposed -SH groups in U-P extracts mainly also for $\mathrm{CN}(64 \%)$ and $\mathrm{T}(100 \%)$ blends.
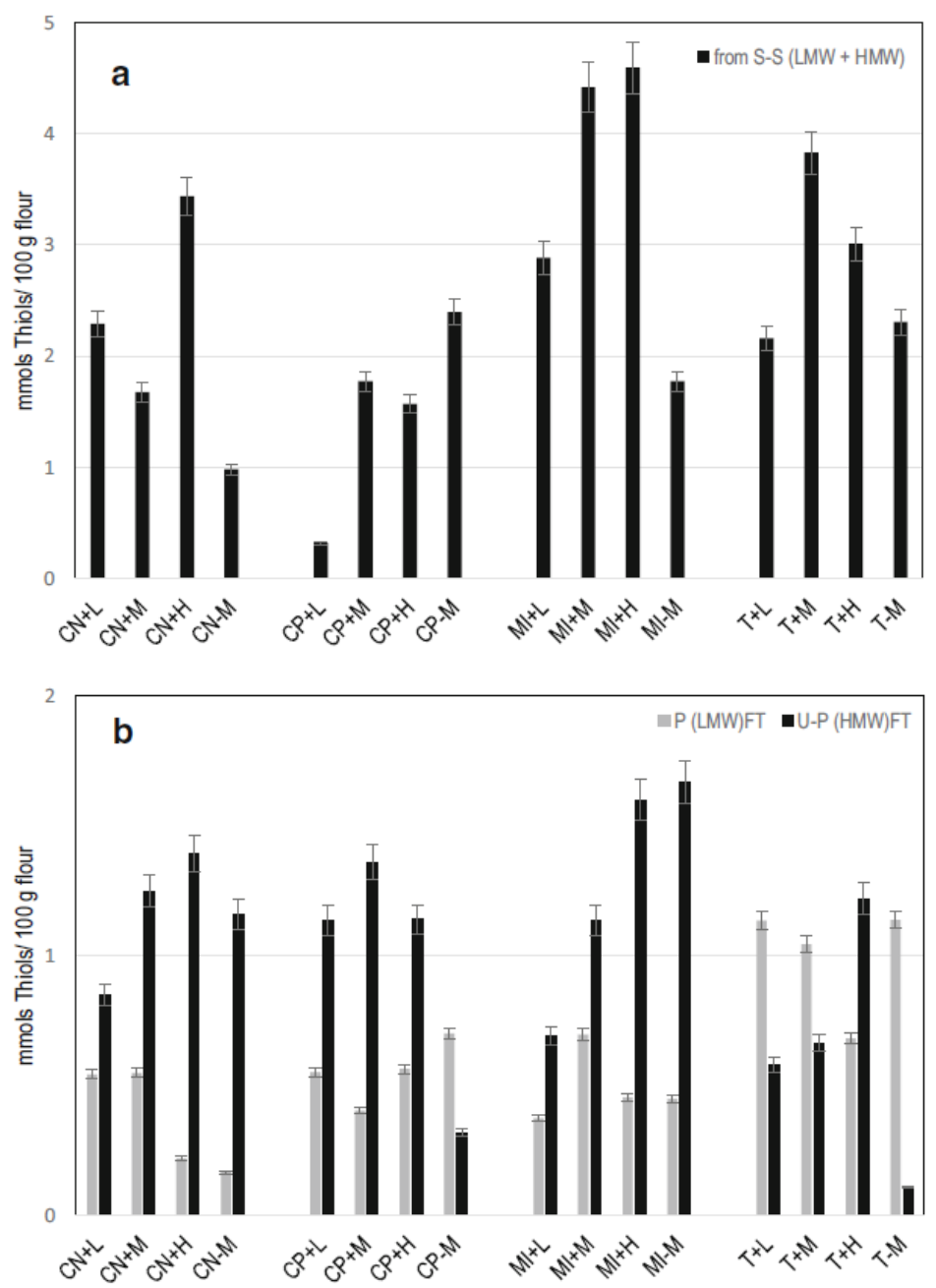

Fig. 3 Accessible thiol content in protein extracts from reduced disulfide bonds D-U (a), and free thiols from lowP- and high molecular weight -U-P- proteins (b) of native (-) and heat-moisture-treated (+) doughs from chestnut $(\mathrm{CN})$, chickpea (CP), millets (MI), and teff (T) blended wheat flours made at low (L), medium (M), and high (H) hydration levels. Water- and salt-soluble proteins were extracted by using phosphate buffer containing $0.05 \mathrm{M}$ $\mathrm{NaH} 2 \mathrm{PO} 4$ and $0.1 \mathrm{M} \mathrm{NaCl}, \mathrm{pH} 7.0$ (buffer P), urea-soluble proteins were extracted using buffer $\mathrm{P}$ with the addition of $6 \mathrm{M}$ urea (buffer $\mathrm{U}$ ), and disulfide bonds were reduced by adding $0.1 \mathrm{M}$ dithiothreitol to the buffer $\mathrm{U}$ (buffer $\mathrm{D}$ )

Results are consistent with changes in the protein molecular conformation that resulted in the exposure of hydrophobic region and SH groups that were initially buried inside the native molecule. With HMT, exposed free SH groups were oxidized to inter- or intramolecular disulfide bonds as observed earlier (Neill et al. 2012; Wang et al. 2017). The formation of a protein network with reinforced compact structure associated to the presence or formation of intra- and intermolecular S-S bonds is feasible to achieve with proteins of non-wheat flour submitted to HMT, particularly in high DY doughs. In a recent research (Wang et al. 2017), the formation of wheat gluten gels on heating is ascribed to interactions 
between proteins, which include covalent interactions (such as disulfide bonds) and non-covalent interactions (such as ionic bonds, hydrogen bonds, and hydrophobic interactions). Authors suggested that wheat gluten unfolded during heat treatment, and the hydrophobic regions and free $\mathrm{SH}$ groups were exposed. When the gelation temperature was greater than $60^{\circ} \mathrm{C}$, crosslinking reactions among the wheat gluten molecules occurred, and subsequently, the unfolded protein chains aggregated via the formation of disulfide bonds and hydrophobic interactions, and the aggregates agglomerated into a threedimensional network. In non-wheat flours, an analogous two-step process (unfolding-aggregation) may take place, being the rate and the extent of the formation of intermolecular disulfide bridges dependent on the protein chain length, number, and exposure of free thiols after unfolding, sterical hindrance, and co-protein effects as stated before (Wang et al. 2016). The level of accessible free SH groups and the surface hydrophobicity of unfolded proteins were the main protein characteristics determining coprotein effects in mixtures with gluten. In fact, the amount of free thiols from high molecular weight proteins negatively correlated ( $\mathrm{p}<0.05$, coefficient of correlation $\mathrm{r}$ ) with $\tau_{\mathrm{cp}}(-0.5018), \gamma_{\max }(-0.5484)$, and $\tau_{\max }(-0.6085)$, evidencing that the lower the amount of free thiols/high crosslinking corresponded to samples that exhibited a solid like elastic structure over higher shear stress and showed increased tolerance to stress/strain before loosing the structure.

\section{Conclusions}

HMT treatment appears as an efficient and clean strategy to enhance in variable extent the viscoelasticity of T, MI, CN, and CP binary blends with wheat flour, depending on both the nature of the non-wheat flour and the hydration level of the matrices. Structuring ability of HMT was mainly observed in cereal flour blends. Higher elastic moduli and lower loss tangent together with solid-like elastic structure over higher shear stress were observed for treated non-wheat cereal flour blends (T, MI) as compared with treated non-cereal flour blends $(\mathrm{CN}, \mathrm{CP})$. Increased flour hydration significantly weakened blends structure, inducing a stepped decrease in dynamic moduli values particularly noticed in cereal blends at highest level of flour hydration, and a shift from elastic-like to viscous- like structure at lower shear stress in non-wheat cereal matrices. Protein denaturation of individual polypeptides and dissociation of non-covalent aggregates significantly led to an increase in the number of accessible thiols in $\mathrm{CN}, \mathrm{CP}$ and MI blends on HMT. The formation of SH-containing water soluble aggregates (CN, MI) and the formation of water insoluble aggregates of higher molecular weight $(\mathrm{CP}, \mathrm{T})$ take place on HMT. Results are consistent with changes in the protein molecular conformation that resulted in the exposure of hydrophobic region and SH groups that were initially buried inside the native molecule. With HMT, exposed free SH groups were oxidized to inter- or intramolecular disulfide bonds. The formation of a protein network with reinforced compact structure associated to the presence or formation of intra- $(\mathrm{CN}$, $\mathrm{CP}, \mathrm{T})$ and intermolecular S-S bonds $(\mathrm{CN}, \mathrm{CP}, \mathrm{MI}, \mathrm{T})$, water-soluble $(\mathrm{CN}, \mathrm{MI})$ and water-insoluble aggregates $(\mathrm{CP}, \mathrm{T})$ is feasible to achieve with proteins of non-wheat flour submitted to HMT, particularly in high DY doughs. The lower the amount of free thiols in high molecular weight proteins encompassing high degree of crosslinking corresponded to thermally treated samples (T+, MI+) blended at low (L) and medium (M) hydration levels. These samples exhibited a solid-like elastic structure over higher shear stress and showed increased tolerance to stress/ strain before losing the structure. 


\section{Acknowledgements}

This study is financially supported by the Institutions Ministerio de Economía y Competitividad (MINECO) and Federación Europea de Desarrollo Regional (FEDER) through the Projects AGL201563849-C2-1-R and AGL2015-63849-C2-2-R, and the Junta de Castilla y León/FEDER VA072P17.

\section{References}

Abebe, Y., Bogale, A., Hambidge, K. M., Stoecker, B., Bailey, J. K., \& Gibson, R. S. (2007). Phytate, zinc, iron and calcium content of selected raw and prepared foods consumed in rural Sidama, southern Ethiopia, and implications for bioavailability. Journal of Food and Composition Analysis, 20, 161-168.

Adebowale, A.-R., Emmambux, N. M., Beukes, M., \& Taylor, J. R. N. (2011). Fractionation and characterization of teff proteins. Journal of Cereal Science, 54, 380-386.

Alamprese, C., Lametti, S., Rossi, M., \& Bergonzi, D. (2005). Role of pasteurisation heat treatments on rheological and protein structural characteristics of fresh egg pasta. European Food Research and Technology, 221, 759-767.

Angioloni, A., \& Collar, C. (2012a). High legume-wheat matrices: an alternative to promote bread nutritional value meeting dough viscoelastic restrictions. European Food Research and Technology, 234(2), 273-284.

Angioloni, A, Collar, C. (2012b). Effects of pressure treatment of hydrated oat, finger millet and sorghum flours on the quality and nutritional properties of composite wheat breads. Journal of Cereal Science, 56, 713-719.

Angioloni, A., \& Collar, C. (2013a). Suitability of Oat, Millet and Sorghum in Breadmaking. Food and Bioprocess Technology, 6, 1486-1493.

Angioloni, A., \& Collar, C. (2013b). Impact of high hydrostatic pressure on protein aggregation and rheological properties of legume batters. Food and Bioprocess Technology, 6, 3576-3584.

Bagdi, A., Balázs, G., Schmidt, J., Szatmári, M., Schoenlechner, R. \& Berghofer, E. (2011). Protein characterization and nutrient composition of Hungarian proso millet varieties and the effect of decortication. Acta Alimentaria, 40, 128-141.

Boye, J., Zare, F., \& Pletch, A. (2010). Pulse proteins: Processing, characterization, functional properties and applications in food and feed. Food Research International, 43, 414-431.

Cho, S.-H., Choi, Y., \& Ha, T.-Y. (2000). In vitro and in vivo effects of proso millet, buckwheat and sorghum on cholesterol metabolism", FASEB Journal, 14, A249,.

Collar, C. (2003). Significance of viscosity profile of pasted and gelled formulated wheat doughs on bread staling. European Food Research and Technology 216, 505-513.

Collar, C. (2016). Role of Bread on Nutrition and Health Worldwide. In: Bread and its fortification. Nutritional and health benefits. Edited by C M. Rosell, J Bajerska, A. F. El Sheikha Publisher: CRC Press/ Taylor \& Francis Group, Boca Ratón, FL, p. 26-52.

Collar, C. (2017). Significance of heat moisture treatment conditions on the pasting and gelling behaviour of various starch-rich cereal and pseudocereal flours. Food Science and Technology International, 23, 623-636. 
Collar, C., \& Angioloni, A. (2017). High-legume wheat-based matrices: impact of high pressure on starch hydrolysis and firming kinetics of composite breads. Food and Bioprocess Technology, 10, 1103-1112.

Collar, C., Armero, E. (2018a). Impact of heat moisture treatment and hydration level on physico-chemical and viscoelastic properties of doughs from wheat-barley composite flours, European Food Research and Technology, 244, 355-366.

Collar, C., \& Armero, E. (2018b). Significance of heat moisture treatment and hydration level of flours on the functional and nutritional value of wheat-barley composite breads. Food and Bioprocess Technology, 11, 966-978.

Collar, C., \& Armero, E. (2018c). Value-added dough-based fermented mixed matrices by applying heat moisture treatment to non-wheat flours: A functional and nutritional approach of blends. Food and Bioprocess Technology, 11, 1536-1551.

Dall'Asta, C., Cirlini, M., Morini, E., Rinaldi, M., Ganino, T., \& Chiavaro, E. (2013). Effect of chestnut flour supplementation on physico-chemical properties and volatiles in bread-making. LWT Food Science and Technology, 53, 233-239.

Delcour, J.A., Joye, I.J., Pareyt, B., Wilderjans, E., Brijs, K., Lagrain, B. (2012). Wheat gluten functionality as a quality determinant in cereal-based food products. Annual Review of Food Science and Technology, 3, 469-492.

FAO/WHO. (2003). Food energy-methods of analysis and conversion factors (p. 77). Rome: FAO Food and Nutrition Paper.

Gulati, P., Li, A., Holding, D., Santra, D., Yue Zhang, Y., \& Rose, D. J. (2017). Heating Reduces Proso Millet Protein Digestibility via Formation of Hydrophobic Aggregates. Journal of Agricultural and Food Chemistry, 65, 1952-1959.

Gunaratne, A., \& Hoover, R. (2002). Effect of heat-moisture treatment on the structure and physicochemical properties of tuber and root starches. Carbohydrate Polymers, 49, 425-437.

Hoover, R. (2010) The Impact of Heat-Moisture Treatment on Molecular Structures and Properties of Starches Isolated from Different Botanical Sources, Critical Reviews in Food Science and Nutrition, 50, 835-847.

ICC (1976-1996). Standard Methods of the International Association for Cereal Science and Technology 104/1, 105/2, 110/1, 136, 162. The Association: Vienna.

Jacobs, H., \& Delcour, J. A. (1998). Hydrothermal modifications of granular starch, with retention of the granular structure: A review. Journal of Agricultural and Food Chemistry, 46, 2895-2905.

Kim, S. K., Choi, H. J., Kang, D. K., \& Kim, H. Y. (2012). Starch properties of native proso millet (Panicum miliaceum L.). Agronomy Research, 10, 311-318.

Kruger, N. J. (2002). The Bradford method for protein quantitation. In J. M. Walker (Ed.), The protein protocols handbook. Totowa: Humana Press Inc

Lambrecht, M. A.,Rombouts, I.,Ketelaere, B. D., \& Delcour, J. A. (2017). Prediction of heat-induced polymerization of different globular food proteins in mixtures with wheat gluten. Food Chemistry, 221, 1158-1167.

Lim, H. S., BeMiller, J. N., \& Lim, S.-T. (2003). Effect of dry heating with ionic gum at controlled pH on starch paste viscosity. Cereal Chemistry, 80, 198-202. 
Lopes-da-Silva, J. A., Santos, D. M. J. Freitas, A., Brites, C., \& Ana M. Gil, A. M. (2007). Rheological and Nuclear Magnetic Resonance (NMR) Study of the Hydration and Heating of Undeveloped Wheat Doughs. Journal of Agricultural and Food Chemistry, 55, 5636-5644.

Mann, J., Schiedt, B., Baumann, A., Conde-Petit, B., \& Vilgis, T. A. (2013). Effect of heat treatment on wheat dough rheology and wheat protein solubility. Food Science and Technology International, 20, 341-351.

Neill, G., Al-Muhtase, A. H., \& Magee, T. R. A. (2012). Optimisation of time/temperature treatment, for heat treated soft wheat flour. Journal of Food Engineering, 113, 422-426.

Paciulli, M., Rinaldi, M., Cirlini, M., Scazzina, F., \& Chiavaro, E. (2016). Chestnut flour addition in commercial gluten-free bread: a shelf-life study. LWT - Food Science and Technology, 70, 8895.

Renzetti, S., Dal Bello, F., \& Arendt, E. K. (2008). Microstructure, fundamental rheology and baking characteristics of batters and breads from different gluten-free fours treated with a microbial transglutaminase. Journal of Cereal Science, 48, 33-45.

Ronda, F., Abebe,W., Pérez-Quirce, S.,\&Collar, C. (2015). Suitability of tef varieties in mixed wheat flour bread matrices: a physicochemical and nutritional approach. Journal of Cereal Science, 64, 139-146.

Ronda, F., Pérez-Quirce, S., Angioloni, A., Collar, C. (2013). Impact of viscous dietary fibres on the viscoelastic behaviour of gluten-free formulated rice doughs: A fundamental and empirical rheological approach. Food Hydrocolloids, 32, 252-262.

Schober, T. J., Bean, S. R., Tilley, M., Smith, B. M., Ioerger B. P. (2011). Impact of different isolation procedures on the functionality of zein and kafirin. Journal of Cereal Science, 54, 241-249.

Sun, Q., Gong, M., Li, Y., Xiong, L. (2014). Effect of dry heat treatment on the physicochemical properties and structure of proso millet flour and starch. Carbohydrate Polymers, 110, 128-134.

Vu, T. H., Bean, S., Hsieh, C. F., \& Yong-Cheng Shi (2017). Changes in protein and starch digestibility in sorghum flour during heat-moisture treatments. Journal of the Science of Food and Agriculture, 97, 4770-4779.

Wang, K.-Q., Luo, S.-Z., Zhong, X.-Y., Cai, J., Jiang, S.-T., Zheng, Z. (2017). Changes in chemical interactions and protein conformation during heat-induced wheat gluten gel formation. Food Chemistry, 214, 393-399.

Wang, X.-Y., Guo, X.-N., Zhu, K.-X. (2016). Polymerization of wheat gluten and the changes of glutenin macropolymer (GMP) during the production of Chinese steamed bread. Food Chemistry, 201, 275-283. 